\title{
A Successful Kindergarten Transition for Children with Disabilities: Collaboration Throughout the Process
}

\author{
Michelle M. Sands ${ }^{1}$ (D) $\cdot$ Hedda Meadan $^{2}$ (D)
}

Accepted: 22 July 2021 / Published online: 11 August 2021

(c) The Author(s), under exclusive licence to Springer Nature B.V. 2021

\begin{abstract}
The transition to kindergarten can be a memorable, yet stressful time for children and families. For children with disabilities and their caregivers, the transition to kindergarten can be especially difficult due to changes in environment, supports, and services that occur as part of the transition. The purpose of this article is to highlight specific practices and strategies that can enhance collaboration throughout the transition to kindergarten. Fictional vignettes are used to describe the perspectives of, and also the practices and strategies used by, members of an education team as they support a child with a disability and her caregiver. Readers are provided with examples of practices and planning tools that can be used to support children with disabilities throughout the transition to kindergarten process. High-intensity transition practices and strategies that can be used before, during, and after kindergarten transition are specifically highlighted. Additionally, the need for both preschool and kindergarten collaboration and support is emphasized.
\end{abstract}

Keywords Transition $\cdot$ Kindergarten $\cdot$ Preschool $\cdot$ Disabilities $\cdot$ Collaboration

\section{Introduction}

Talia receives special education services and supports within a half-day, blended preschool classroom at Stonebridge School District's Early Childhood Center. An outgoing 5-year-old, she has developmental delays and receives support from her preschool special education teacher in an inclusive setting. Talia also receives speech-language therapy, occupational therapy, and services and support from a social worker. During parent-teacher conferences, her preschool teacher asks Talia's mom, Naomi, if she has any questions about her child's transition to full-day kindergarten. "I'm not sure. But, I hate to think about leaving the preschool program. We love it here. I'm not sure if Talia's even ready for kindergarten. Aren't the expectations in kindergarten different? What will her day look like? How will

Michelle M. Sands

sandsm@uwosh.edu

Hedda Meadan

meadan@illinois.edu

1 Department of Special and Early Childhood Education, University of Wisconsin-Oshkosh, Oshkosh, WI, USA

2 Department of Special Education, University of Illinois at Urbana-Champaign, Champaign, IL, USA she get the support she needs if she is in a general education classroom? I feel like we are heading into the unknown." While the preschool teacher has nurtured a strong relationship with Naomi and wants to make sure Talia's transition to kindergarten is smooth, she is not sure how many of the things she has implemented in the preschool classroom will be feasible in the kindergarten classroom at the elementary school. She wonders what she can do to make sure Naomi and Talia have the support needed to make the transition successful.

\section{The Need for Collaboration Throughout the Transition to Kindergarten}

Each year, many children served as part of the early childhood special education services under Part B of the Individuals with Disabilities Education Act (IDEA, 2004) make the transition from preschool to kindergarten and may encounter changes in classroom environments, including setting, size, and expectations (Gill et al., 2006). Because children with disabilities may have limited social-emotional and/or academic competencies to support them during this time of change, the transition to kindergarten may be particularly difficult (McIntyre et al., 2010). In this article, we 
highlight transition practices and strategies that enhance collaboration throughout (before, during, and after) the transition of children with disabilities to kindergarten and which align with the Division for Early Childhood's (DEC) Recommended Practices for transition (2014). Fictional vignettes created by the authors were based on real scenarios and designed to illustrate practices and strategies used to support Talia, a child with a developmental delay, and her mother, Naomi during her final year of preschool, during the transition to kindergarten, and after her first few weeks in kindergarten. The DEC Recommended Practices support practitioners, including teachers and support staff, as they pursue the ultimate goal of transition - "to support children with disabilities' developmental, academic, and social success in the next environment" (Rous et al., 2007a, 2007b). Because transition is a process that begins prior to a child's actual departure from a program and continues as a child and family acclimate to the new environment, creating opportunities throughout this transition process where preschool and kindergarten staff can share information, and implement activities and experiences using strategies that will promote a child and family's successful adjustment and positive outcomes is essential (DEC, 2014). Programs and practitioners can determine how to best support individual children with disabilities by establishing early opportunities to understand future environments and critical factors related to classroom or teacher, family, and child characteristics (Rous \& Hallam, 2012).

While researchers have focused on supporting interagency collaboration or supporting families and children during transition (Branson \& Bingham, 2009; Connelly, 2007), past research has focused primarily on the transition from EI to preschool. However, the transition to kindergarten is unique as many parents still perceive kindergarten as the start of a child's academic career. Additionally, while preschool classrooms are strongly encouraged to use familycentered practices (Division for Early Childhood, 2014) and often do make an attempt to use a family-focused approach, many elementary schools may or should desire family engagement yet utilize a more child-centered approach. Additionally, for children with disabilities, the transition process may include changes in eligibility, future placement, services, and instructional support-all of which can further challenge a child's successful transition to kindergarten (U.S. Department of Education, 2009, 2016). For these children, the already challenging transition to kindergarten can include less support and monitoring than what they had received in preschool, and in some cases fewer opportunities to participate in general education settings (Guralnick et al., 2008). The effective use of kindergarten transition practices may increase opportunities for inclusion by engaging staff, families, and community members in collaborative processes in which alignment and continuity of inclusive practices between preschool and kindergarten can better occur.

Concerns about the kindergarten transition process are expressed more often from families of children with disabilities, when compared to families of children who are typically developing (Welchons \& McIntyre, 2015). Researchers believe possible reasons for the additional concerns may be the planning meeting decisions and eligibility determinations that may accompany the transition process for children with disabilities. Parents who have children with disabilities often feel the need to demonstrate strong advocacy during the transition to kindergarten (Burke et al., 2016) and teachers express concerns regarding this process (Welchons \& McIntyre, 2015). General education teachers may have a desire to participate in the transition process but face barriers in doing so, and may lack an understanding of how to support diverse learners in their classrooms (Walker et al., 2012). Furthermore, for children who are culturally and/or linguistically diverse participation, the transition process may need to include additional staff that can ensure family's full participation and address strategies to ensure cultural responsivity (Rivera et al., 2020; Acar \& Blasco, 2018).

The Transition Process for Young Children with Disabilities conceptual framework (Rous \& Hallam, 2006; Rous et al., 2007a, 2007b) is based on the idea that "the goal of transition is the child's developmental, academic and social success in the next environment" (Rous et al., 2007a, 2007b, p. 158). The framework is based on ecological (Bronfenbrenner, 1979) and organizational theories (Shafritz \& Ott, 2005) and is specific to the bioecological forces (i.e., child, family, and community factors) that influence the experiences of young children and their families. In their expanded conceptual model, Gooden and Rous (2018) describe three key elements of the transition process for children with disabilities (i.e., relationships, collaboration and training, and individualized services). Use of transition practices and strategies throughout the transition process can help support a child and family's adjustment to a new environment and lead to positive child outcomes.

\section{Transition Practices and Strategies}

Researchers have categorized different types of kindergarten transition practices, by intensity and procedure. High-intensity transition practices are individualized for certain children (e.g., phone calls, home visits, planning meetings), while low-intensity transition practices are not (e.g., providing handouts, facilitating general information meetings) (Daley et al., 2011; Pianta et al., 1999). Formal transition practices are often routinely conducted and based on local or state policies (e.g., open houses, conferences, meetings; Rimm-Kaufman \& Pianta, 2000), whereas informal transition practices may be offered less 
uniformly across programs (e.g., phone calls, parent/ teacher conversations, conversations with kindergarten teachers). For children with disabilities, transition practices that are high-intensity or individualized can address and support the specific strengths, needs, and characteristics of individual children and families (Rous, Meyers et al., 2007a, b; Rous \& Hallam, 2012). However, kindergarten transition practices used to support young children with disabilities and their families are often low-intensity and lack teacher collaboration (Daley et al., 2011; La Paro et al., 2000; Quintero \& McIntyre, 2011; Rous et al., 2007a, b; Welchons \& McIntyre, 2015).

While transition practices are "key elements of transition planning that are regularly and consistently implemented across staff and programs," transition strategies are "specific program or classroom activities used to implement a practice" (National Early Childhood Transition Center, 2011, p. 1). Use of transition strategies that are differentiated to support individual children as they transition to kindergarten can facilitate program continuity while also allowing for the individualization necessary based on a specific context, or at a child or family level (Rous, 2008; Rous \& Hallam, 2012; Rous et al., 2010).

\section{Collaboration and Support Throughout the Transition Process}

Although there has been a large body of literature focused on the need for interagency collaboration as children transition from IDEA Part $C$ (early intervention services) to IDEA Part B (school-age special education), collaboration and support within district grade levels or programs is equally as important during the transition from preschool to kindergarten. Creating opportunities for collaboration between preschool and kindergarten teachers may require creativity and flexibility, but it can lead to positive child outcomes (Rous et al., 2006). Preschool and kindergarten teacher communication during transition has been positively associated with kindergarten teachers' positive perceptions of children's social skills (Cook et al., 2017; LoCasale-Crouch et al., 2008).

Successfully supporting children with disabilities as they transition is an ongoing process that requires collaboration and support. Researchers have suggested transition collaboration and support begin when a child is still in preschool, and then continue as a child begins kindergarten, and even after a child has spent several weeks in the new kindergarten classroom (Rous et al., 2006; see Table 1). The fictional vignette illustrates moments during the transition to kindergarten process from the perspective of a preschool special education teacher, a parent, and a kindergarten teacher, and highlights the use of various transition practices and strategies to support a child with a disability.

\section{During the Final Year of Preschool}

Naomi appreciated that the preschool teacher had shared her questions and concerns about the transition to kindergarten with a kindergarten general education teacher and a special education teacher at their neighborhood elementary school. When she received a call from the kindergarten teachers to arrange a visit to their classroom, Naomi was relieved but also anxious. She had heard that the expectations in kindergarten had changed a lot since she was in school and knew that the number of children in the general education kindergarten classroom was larger than in the preschool classrooms. When Naomi and Talia arrived, the kindergarten teachers introduced themselves and gave both a chance to look around and observe during large group time and center time. While the children went to music class, the kindergarten teachers answered Naomi's questions about the transition process and kindergarten expectations. After the visit, Naomi and Talia both had a better idea of what a kindergarten looked like and some of the expectations. Naomi also felt more comfortable scheduling the transition planning meeting with the preschool teacher, kindergarten teachers and support staff.

Families will feel more confident about the transition to kindergarten if they know that preschool and kindergarten staff have established positive and collaborative relationships with one another. Therefore, preschool programs and kindergarten or elementary staff, including general and special education teachers, need to prioritize having opportunities to meet and plan for individual children's transition to kindergarten. Ideally, these meetings would include all members of a child's current educational team, in addition to those who will serve the child in the kindergarten setting. Preschool and kindergarten teachers have both expressed the need for more opportunities to collaborate with one another and with families (Rous et al., 2010) and ongoing opportunities to do so could be used to better understand and align developmentally appropriate program expectations, and identify general and individualized kindergarten transition practices as well as roles and responsibilities of staff. Opportunities to visit possible placements, and collaboratively plan for the transition to kindergarten, provide families with opportunities to meet with preschool and kindergarten practitioners and familiarize themselves with the staff, environments, and expectations. It also provides families with an opportunity to share their child's unique history, strengths and needs with kindergarten practitioners. Preschool and kindergarten staff (e.g., teachers, speech-language pathologists, school psychologist, etc.) should be in communication prior to visits and transition planning meetings to ensure each have the 
information that may be needed to prepare for these activities (e.g. child's current IEP, etc.). Together as a transition team, families, preschool and kindergarten practitioners can then create individualized plans for transition to kindergarten (see example Fig. 1).

As part of an individualized transition plan, teams should consider establishing specific transition goals for a child based on their strengths and needs, as well as parents' desires. Then, a child's team can discuss the individualized practices to use to support the child's achievement of these goals. Teams can then identify accommodations or modifications that might be used to support implementation of these practices. Accommodations and modifications can range from specific materials (e.g., social story, visual schedule, sensory supports) to additional support (e.g., peer model, 1:1 assistance), and also can include modifications

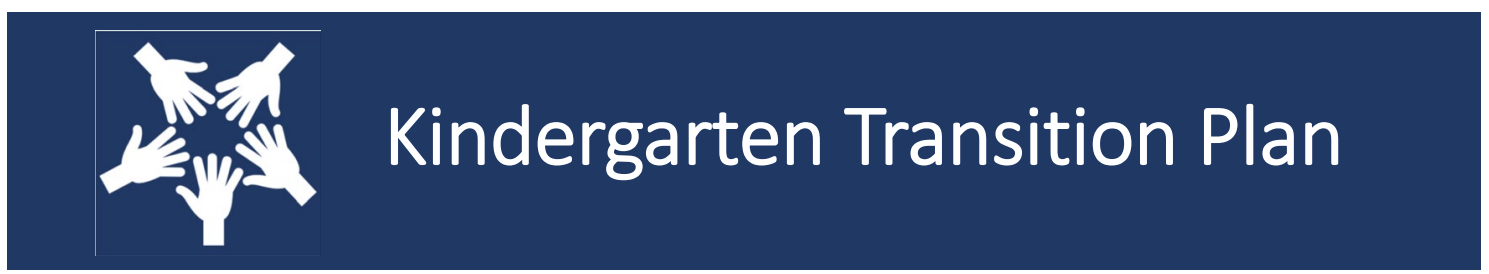

The information below should be determined as a kindergarten transition planning team and should include contributions from parents/caregivers and practitioners who are directly working with a child or who will be in the upcoming school year.

\begin{tabular}{|c|c|c|c|}
\hline Talia Davis & $5 / 7 / 2015$ & $8 / 31 / 2020$ & $8: 05 \mathrm{AM}-2: 50 \mathrm{PM}$ \\
\hline Child's Name & Date of Birth & First Day of $\mathrm{K}$ & Start/End Times \\
\hline $2 / 1 / 2021$ & $1 / 26 / 2023$ & $\begin{array}{l}\text { Mark Twain } \\
\text { Elementary }\end{array}$ & Naomi Williams (Mother) \\
\hline Annual Review Due & $\begin{array}{l}\text { Reevaluation } \\
\text { Due }\end{array}$ & Elementary School & Primary Contact \\
\hline
\end{tabular}

\begin{tabular}{|l|l|}
\hline $\begin{array}{l}\text { What are some of the family's strengths that will } \\
\text { help her successfully transition to kindergarten? }\end{array}$ & $\begin{array}{l}\text { Both of Talia's parents are familiar with how to use social stories and } \\
\text { visuals to help her during transitions. Both are eager to collaborate } \\
\text { with kindergarten team members. }\end{array}$ \\
\hline $\begin{array}{l}\text { What are some of the child's individual strengths } \\
\text { that will help her successfully transition to } \\
\text { kindergarten? }\end{array}$ & $\begin{array}{l}\text { Talia currently uses social stories and visual cues/schedule to help her } \\
\text { understand expectations or to support her during transition. She uses } \\
\text { 3-4 word sentences to communicate her needs/wants. }\end{array}$ \\
\hline
\end{tabular}

\begin{tabular}{|c|c|c|c|}
\hline \multicolumn{2}{|c|}{$\begin{array}{c}\text { What is needed to best support family's adjustment } \\
\text { during the transition to kindergarten? }\end{array}$} & Related Transition Activity/Strategy & $\begin{array}{l}\text { Person(s) Responsible } \\
\text { and Roles: }\end{array}$ \\
\hline \multicolumn{2}{|c|}{$\begin{array}{l}\text { Talia's parents have requested a copy of their child's } \\
\text { daily schedule to facilitate conversations at home } \\
\text { about her day. }\end{array}$} & $\begin{array}{l}\text { Talia and her parents will visit the } \\
\text { kindergarten classroom and walkthrough } \\
\text { her daily schedule with teachers before } \\
\text { the school year begins. A copy of the } \\
\text { schedule will be provided. }\end{array}$ & $\begin{array}{l}\text { K General Education and } \\
\text { Special Education } \\
\text { Teachers }\end{array}$ \\
\hline \multicolumn{2}{|c|}{$\begin{array}{l}\text { Talia's parents have requested that a copy of the } \\
\text { classroom expectations be provided before the start } \\
\text { of the year for them to review together over the } \\
\text { summer. }\end{array}$} & $\begin{array}{l}\text { A personal copy of visual classroom } \\
\text { expectations will be sent home at the } \\
\text { beginning of the summer. }\end{array}$ & $\begin{array}{c}\text { K General Education and } \\
\text { Special Education } \\
\text { Teachers }\end{array}$ \\
\hline $\begin{array}{l}\text { What is needed to best support the } \\
\text { child's adjustment and success during } \\
\text { the transition to kindergarten? }\end{array}$ & $\begin{array}{l}\text { Related } \\
\text { Goal(s) }\end{array}$ & Related Transition Activity/Strategy & $\begin{array}{l}\text { Person(s) Responsible } \\
\text { and Roles: }\end{array}$ \\
\hline $\begin{array}{l}\text { Talia needs visual supports and verbal } \\
\text { reminders to help her successfully } \\
\text { transition between activities } \\
\text { throughout the day. }\end{array}$ & Goal 1 & $\begin{array}{l}\text { A visual schedule will be posted in every } \\
\text { classroom and Talia will have access to a } \\
\text { personal visual schedule at her desk. } \\
\text { Teachers will provide her with verbal cues } \\
\text { to when an activity is ending/beginning. }\end{array}$ & $\begin{array}{c}\text { K General Education and } \\
\text { K Special Education } \\
\text { Teachers }\end{array}$ \\
\hline $\begin{array}{l}\text { Talia needs visual and verbal } \\
\text { reminders of classroom expectations to } \\
\text { successfully engage with peers and } \\
\text { adults. }\end{array}$ & Goal 2 & $\begin{array}{l}\text { Each classroom will have classroom } \\
\text { expectations posted visually. Talia will } \\
\text { have access to a personal copy of } \\
\text { classroom expectations at her seat. }\end{array}$ & $\begin{array}{c}\text { K General Education and } \\
\text { K Special Education } \\
\text { Teachers }\end{array}$ \\
\hline
\end{tabular}

Fig. 1 An example of an individualized kindergarten transition plan 


\section{TRANSITION TO KINDERGARTEN}

Kindergarten Transition Team Members:

\begin{tabular}{|c|c|c|c|}
\hline \multicolumn{2}{|c|}{ Parent/Caregiver: Naomi Williams } & \multicolumn{2}{|c|}{ Phone/Email: (555) 555-5555 / abcd@xyz.org } \\
\hline \multicolumn{2}{|c|}{ Parent/Caregiver: Martin Davis } & \multicolumn{2}{|c|}{ Phone/Email: (555) 555-5555 / wxyz@abd.org } \\
\hline \multicolumn{2}{|c|}{ Preschool Staff: } & \multicolumn{2}{|c|}{ Elementary Staff: } \\
\hline $\begin{array}{l}\text { Teacher Name: } \\
\text { Lianne Stow }\end{array}$ & $\begin{array}{l}\text { Phone/Email: (555) 555- } \\
5555 \text { / efgh@sdxxx.org }\end{array}$ & $\begin{array}{l}\text { General Education } \\
\text { Teacher Name: } \\
\text { Alexis Cross }\end{array}$ & $\begin{array}{l}\text { Phone/Email: (555) 555- } \\
5555 \text { / efgh@sdxxx.org }\end{array}$ \\
\hline & & $\begin{array}{l}\text { Special Education } \\
\text { Teacher Name: } \\
\text { Matt Douglas } \\
\end{array}$ & $\begin{array}{l}\text { Phone/Email: (555) 555- } \\
5555 \text { / efgh@sdxxx.org }\end{array}$ \\
\hline $\begin{array}{l}\text { Services: } \\
\text { Speech/Language } \\
\text { Name: Lori Yoo }\end{array}$ & $\begin{array}{l}\text { Phone/Email: (555) 555- } \\
5555 \text { / efgh@sdxxx.org }\end{array}$ & $\begin{array}{l}\text { Services: } \\
\text { Speech/Language } \\
\text { Name: Wendy Manna }\end{array}$ & $\begin{array}{l}\text { Phone/Email: (555) 555- } \\
5555 \text { / efgh@sdxxx.org }\end{array}$ \\
\hline $\begin{array}{l}\text { Services: Occupational } \\
\text { Therapy } \\
\text { Name: Tori Andrews }\end{array}$ & $\begin{array}{l}\text { Phone/Email: (555) 555- } \\
5555 \text { / efgh@sdxxx.org }\end{array}$ & $\begin{array}{l}\text { Services: } \\
\text { Occupational Therapy } \\
\text { Name: Kinara } \\
\text { Thomas }\end{array}$ & $\begin{array}{l}\text { Phone/Email: } \\
\text { (555) 555-5555 / } \\
\text { efgh@sdxxx.org }\end{array}$ \\
\hline $\begin{array}{l}\text { Administrator Name: } \\
\text { Donna Brook }\end{array}$ & $\begin{array}{l}\text { Phone/Email: (555) 555- } \\
5555 \text { / efgh@sdxxx.org }\end{array}$ & $\begin{array}{l}\text { Administrator } \\
\text { Name: } \\
\text { Janet Fox }\end{array}$ & $\begin{array}{l}\text { Phone/Email: (555) 555- } \\
5555 \text { / efgh@sdxxx.org }\end{array}$ \\
\hline
\end{tabular}

\section{All kindergarten transition team members have received:}

$\square$ A copy of this Kindergarten Transition Plan.

$\square$ A timeline of transition activities scheduled at child's preschool and elementary buildings.

$\square$ A copy of the child's current IEP.

Fig. 1 (continued)

such as changes to the daily schedule and seating arrangement. Lastly, teams should determine what information they will collect throughout the transition process (e.g., anecdotal notes, systematic observations) to evaluate the child's progress towards goals and the effectiveness of the transition practices and strategies. By working together to create and implement a comprehensive transition plan, team members (parents, preschool teachers and staff, and kindergarten teachers and staff) can develop a common understanding of how to best support child success in the new environment, what their roles/responsibilities are, and whether or not they have been successful.

\section{During the Child's Transition to Kindergarten}

The kindergarten special education teacher receives an email over the summer from Naomi, Talia's mom. In the email, Naomi shares that Talia had recently been seen by their pediatrician and he has referred her to an audiologist with concerns about her hearing. Based on the communication plan that was created together with Talia's preschool teachers, both of the kindergarten teachers, and others at the transition planning meeting, Naomi wanted to know if the team could meet prior to the start of the school year to discuss the results of the audiologist's findings. Since the kindergarten special education teacher was designated by the transition team as the primary contact, and because he had called to touch base with Naomi the month prior, he shares this information with the rest of the team and gives mom a call to schedule a meeting for the week prior to school starting. When scheduling the meeting, he reminds Naomi about the meet and greet event for kindergarteners and their families that week. Naomi thanks him and adds the date of their team meeting to the timeline of general and individualized transition activities she had received from the team at the transition planning meeting in April. The teacher lets Naomi know that if anything changes or comes up prior to the team meeting, she should feel free to contact him.

The transition to kindergarten often occurs immediately after a summer break. Yet, maintaining communication over 
the summer months can be challenging due to changes in staff and family availability and contact information. One way to ensure communication is maintained during these months is to establish a communication plan and designate one practitioner on a child's kindergarten team to serve as a primary contact. Changes that occur related to a child's abilities, needs, or staffing, and parent concerns and questions may necessitate updating a child's transition plan or accessing additional resources. To ensure that teams are able to take proactive measures to address a child's needs, parents and the primary contact might schedule opportunities to touch base several times during the summer. Additionally, the collaborative creation of a timeline that can be distributed to families and practitioners, and that includes a schedule of individualized activities and scheduled contact meetings would support a family's and staff's involvement throughout the summer leading into the child's transition to kindergarten (see example in Fig. 2).

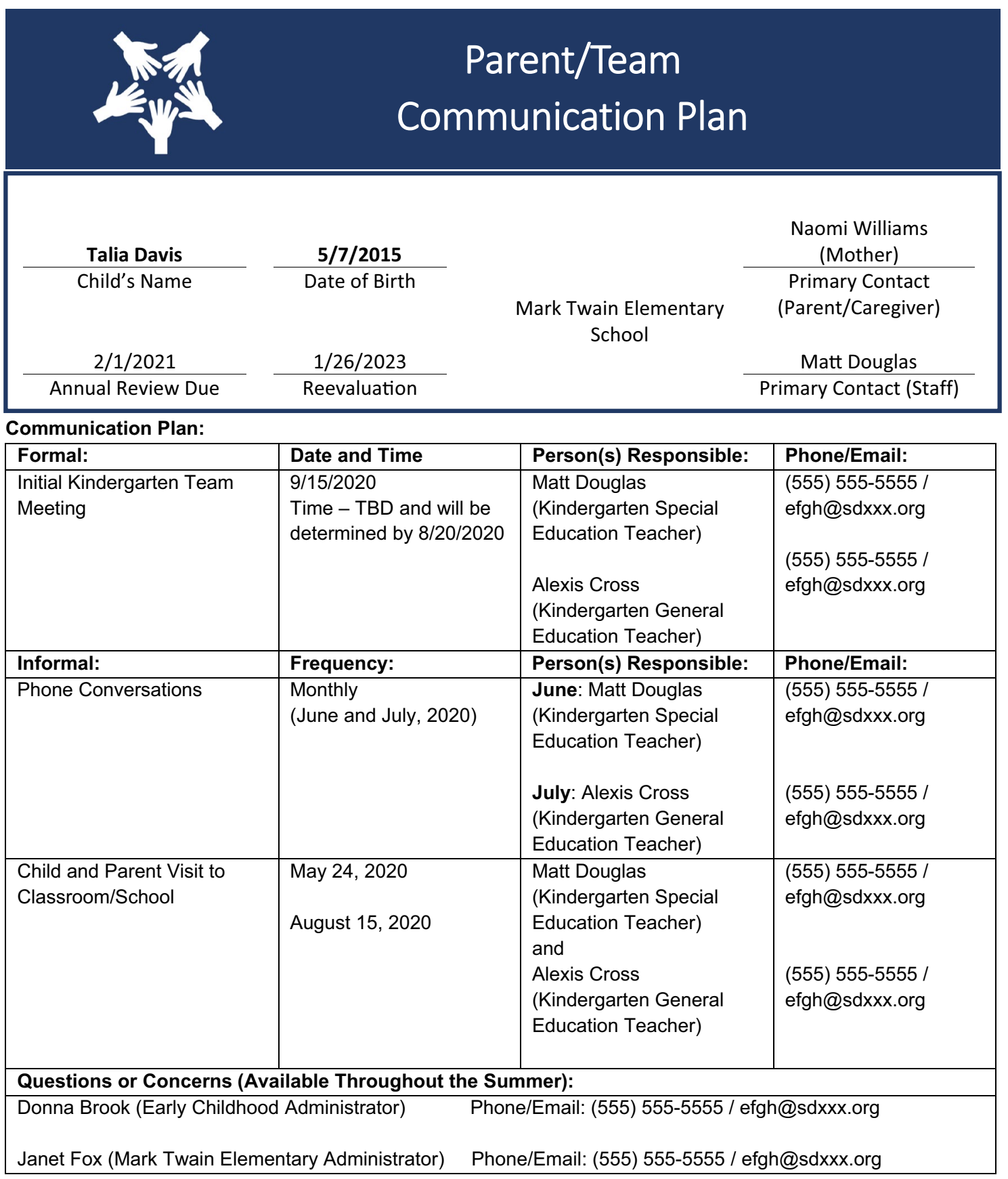

Fig. 2 An example of a kindergarten transition communication plan 
As the school year begins, collaboration between families and preschool and kindergarten teachers remains important. Preschool teachers and staff may already be familiar with a child and their family, whereas at the start of the year kindergarten teachers and staff will be building rapport with a child and their family and becoming familiar with the child's strengths and needs within the new environment. Working together, families and practitioners can create unique experiences for children with disabilities and their families at the start of the year to ensure each child and member of their transition team feels supported. One example of intra-agency collaboration is hosting a welcome week at the elementary school where preschool and kindergarten teachers and team members spend the first couple of days of kindergarten welcoming children together. In this scenario, a district establishes a slow start for their preschool program and children come for $30 \mathrm{~min}$ the first two days to allow teachers and team members to then use the rest of their day working alongside kindergarten teachers and staff to support the first two full days of kindergarten together. This action supports all children as they adjust to the different environment and allows preschool teachers an opportunity to provide kindergarten staff with guidance and support regarding implementation of individualized strategies that have been used with specific children in the past. While this type of collaboration may require state and local administrator support, it can be beneficial for everyone involved-children and parents see a familiar face in the new environment, kindergarten teachers are provided with additional support during a typically hectic time, and preschool teachers have another opportunity to observe a kindergarten classroom and learn how they might better prepare children for such a transition. Other ideas for collaboration and communication at the start of the year include kindergarten home visits, and kindergarten and preschool teacher co-planning lessons for the first few weeks of school.

\section{After a Child's First Few Weeks of Kindergarten}

On the second day of kindergarten, Naomi receives a call from Talia's kindergarten general education teacher. She lets Naomi know that while Talia needed one-on-one support from the special education teacher, to transition to the library early in the day and back to the classroom after recess, she transitioned independently to music class in the afternoon. Naomi asked if she thought it was helpful that the preschool teacher was available the first week to model how she used the visual schedule with Talia to help prepare her for transitions throughout the day. "I did," said the teacher. "I hadn't used a visual schedule like that before, so it really helped that she was able to show all of us on the team how Talia could use it." The kindergarten teacher then explained that the distance to the library could possibly be the reason that Talia struggled with the transition. The teacher mentioned to Naomi that she and the special education teacher thought they might possibly ask Talia to carry some of the library books to the library next week as one way to possibly keep her more on-task during the transition. "What do you think of that idea?" "I think that's a great idea. Talia loves to be a helper," said Naomi. As part of a communication plan that the kindergarten teacher team established with Naomi before the end of Talia's preschool year, parents and teachers continue to collaborate and communicate throughout the start of the new school year to ensure that together they can modify any changes that might need to be made to the original transition plan. This ensures Naomi understands how she can work together with the team to best support Talia's transition, and that she can help the team assess the success of the transition.

After the first few weeks of kindergarten, the chance to meet as a transition team is an opportunity for families and staff to share and discuss child progress towards goals and problem solve any concerns with a variety of team members. Including preschool and kindergarten team members as part of this meeting also provides an opportunity for the group to discuss implementation of the transition practices and strategies, review data collected during the transition process, and assess if the transition practices and strategies were effective in supporting the child's achievement of the targeted goals. Opportunities for parents, and the kindergarten and preschool teams to reflect can help determine next steps and things to consider when planning children' transition to kindergarten.

\section{Conclusion}

As previously mentioned, supporting successful kindergarten transitions for children with disabilities and their families is contingent on the collaboration and communication that occurs throughout the transition process (Hojnoski \& Missall, 2020; Rous et al., 2006). Furthermore, it is important that families and staff are actively engaged in the transition process and are provided opportunities to share information and ideas, ask questions, and when needed, problem solve ways to support their child's desired outcomes (Rous et al., 2020; Starr et al., 2016).

With this in mind, it is important for teachers and staff to ensure that all members of a child's preschool and kindergarten team have opportunities to plan, collaborate, and have open communication throughout the transition process. High-intensity transition practices, such as individualized transition planning meetings or one-on-one classroom visits, may require more coordination of resources, yet they provide the best opportunity for members of the child's educational team, including families, to connect and collaborate. 
Additionally, high-intensity transition practices can best support the individual strengths and needs of children and families (Rous \& Hallam, 2012; Rous et al., 2007a, b) during what can be a challenging transition to kindergarten.

Because research has found that a majority of transition practices used by teachers are low-intensity or lack collaboration between preschool and kindergarten (Daley et al., 2011; La Paro et al., 2000; Quintero \& McIntyre, 2011; Rous et al., 2007a, 2007b; Welchons \& McIntyre, 2015), additional research is needed to better understand the barriers to use of high-intensity transition practices and potential ways of addressing these. Researchers should also consider exploring how technologies such as teleconference, text messaging, and other communication applications may enhance or ease classroom or programs' use of these recommended practices, especially in response to COVID-19. Finally, there exists limited research to describe to what extent use of highintensity transition practices can impact a child's social or academic outcomes in kindergarten, or which high-intensity transition practices may have more of an effect in compared to others. By understanding which high-intensity transition practices have a more significant impact on positive child and family outcomes, this could help individuals in the field prioritize their use.

Supplementary Information The online version contains supplementary material available at https://doi.org/10.1007/s10643-021-01246-6.

Funding This study was supported in part by funding from the Office of Special Education Programs, U.S. Department of Education, Project IMPACT (H325D150036). The views or opinions presented in this manuscript are solely those of the authors and do not necessarily represent those of the funding agency.

Data Availability Not applicable.

Code Availability Not applicable.

\section{Declarations}

Conflict of interest Not applicable.

\section{References}

Acar, S., \& Blasco, P. M. (2018). Guidelines for collaborating with interpreters in early intervention/early childhood special education. Young Exceptional Children, 21(3), 170-184. https://doi.org/ $10.1177 / 1096250616674516$

Branson, D. M., \& Bingham, A. (2009). Using interagency collaboration to support family-centered transition practices. Young Exceptional Children, 12(3), 15-31. https://doi.org/10.1177/2F109 6250609332306

Bronfenbrenner, U. (1979). The ecology of human development: Experiments by nature and design. Harvard University Press.

Burke, M. M., Patton, K. A., \& Lee, C. E. (2016). Parent advocacy across the lifespan. International Review of Research in
Developmental Disabilities, 51, 193-231. https://doi.org/10.1016/ bs.irrdd.2016.07.001

Connelly, A. M. (2007). Transitions of families from early intervention to preschool intervention for children with disabilities. Young Exceptional Children, 10(3), 10-16. https://doi.org/10.1177/ 2F109625060701000302

Cook, K. D., Dearning, E., \& Zachrisson, H. D. (2017). Information sharing between teachers and early education programs during school entry in Norway: Associations with children's school adjustment and success in the first year. International Journal of Child Care and Education Policy, 11(1), 14. https://doi.org/10. 1186/s40723-017-0039-5

Daley, T. C., Munk, T., \& Carlsonn, E. (2011). A national study of kindergarte transition practices for children with disabilities. Early Childhood Research Quarterly, 26(4), 409-419. https://doi.org/ 10.1016/j.ecresq.2010.11.001

Division for Early Childhood. (2014). DEC recommended practices in early intervention/early childhood special education 2014. http:// www.dec-sped.org/recommendedpractices

Gill, S., Winters, D., \& Friedman, D. S. (2006). Educators' views of pre-kindergarten and kindergarten readiness and transition practices. Contemporary Issues in Early Childhood, 7(3), 213-227. https://doi.org/10.2304/2Fciec.2006.7.3.213

Gooden, C., \& Rous, B. (2018). Effective transitions to kindergarten for children with disabilities. In A. Mashburn, J. LoCasale-Crouch, \& K. Pears (Eds.), Kindergarten Transition and Readiness. Springer.

Guralnick, M. J., Neville, B., Hammond, M. A., \& Connor, R. T. (2008). Continuity and change from full-inclusion early childhood programs through the early elementary period. Journal of Early Intervention, 30(3), 237-250. https://doi.org/10.1177/2F105 3815108317962

Hojnoski, R. L., \& Missall, K. N. (2020). Supporting all children in the transition from preschool to kindergarten. In B. S. Rous, T. W. McLaughlin, \& S. R. Sandall (Eds.), DEC recommended practices monograph series no. 8 transition: Supporting changes in services and settings. Division for Early Childhood of the Council for Exceptional Children.

Individuals with Disabilities Education Act, 20 U.S.C. § 1400 (2004).

La Paro, K. M., Pianta, R. C., \& Cox, M. J. (2000). Teachers' reported transition practices for children transitioning into kindergarten and first grade. Exceptional Children, 67(1), 7-20. https://doi.org/10. 1177/001440290006700101

LoCasale-Crouch, J., Mashburn, A. J., Downer, J. T., \& Pianta, R. C. (2008). Pre-kindergarten teachers' use of transition practices and children's adjustment to kindergarten. Early Childhood Research Quarterly, 23(1), 124-139. https://doi.org/10.1016/j.ecresq.2007. 06.001

McIntyre, L. L., Eckert, T. L., Fiese, B. H., Reed, F. D., \& Wildenger, L. K. (2010). Family concerns surrounding kindergarten transition: A comparison of students in special and general education. Early Childhood Education Journal, 38, 259-263. https://doi.org/ 10.1007/s10643-010-0416-y

National Early Childhood Transition Center (2011). Effective transition practices \& strategies. NECTC transition tips: Toolkit of practices and strategies. https://www.parentcenterhub.org/wp-content/uploa ds/repo_items/legacy/partc/activity6.pdf

Quintero, N., McIntyre, L. L. (2011). Kindergarten transition preparation: A comparison of teacher and parent practices for children with autism and other developmental disabilities. Early Childhood Education Journal, 38, 411-420. https://doi.org/10.1007/ s10643-010-0427-8

Rimm-Kaufman, S. E., \& Pianta, R. C. (2000). An ecological perspective on the transition to kindergarten: A theoretical framework to guide empirical research. Journal of Applied Developmental Psychology, 21(5), 491-511. https://doi.org/10.1016/S0193-3973(00) 00051-4 
Rivera, C. J., Haughney, K. L., Clark, K. A., \& Werunga, R. (2020). Culturally responsive planning, instruction, and reflection for young children with significant disabilities. Young Exceptional Children. https://doi.org/10.1177/1096250620951767

Rous, B. (2008). Recommended transition practices for young children and families: Results from a national validation survey. (Technical Report \#3). Lexington: University of Kentucky, Human Development Institute, National Early Childhood Transition Center.

Rous, B. S., Gooden, C., Hallam, R., \& Chapman, K. (2020). Using a transition plan to promote individualized transition services. In B. S. Rous, T. W. McLaughlin, \& S. R. Sandall (Eds.), DEC recommended practices monograph series no. 8 transition: Supporting changes in services and settings. Division for Early Childhood of the Council for Exceptional Children.

Rous, B. S., \& Hallam, R. A. (2006). Tools for transition in early childhood: A step-by-step guide for agencies, teachers, \& families. Brookes.

Rous, B. S., \& Hallam, R. (2012). Transition services for young children with disabilities: Research and future directions. Topics in Early Childhood Special Education, 31(4), 232-240. https://doi. org/10.1177/2F0271121411428087

Rous, B., Hallam, R., Harbin, G., McCormick, K., \& Jung, L. (2007a). The transition process for young children with disabilities: A conceptual framework. Infants and Young Children, 20(2), 135-148. https://doi.org/10.1097/01.IYC.0000264481.27947.5f

Rous, B., Hallam, R., McCormick, K., \& Cox, M. (2010). Practices that support the transition to public preschool programs: Results from a national survey. Early Childhood Research Quarterly, 25(1), 17-32. https://doi.org/10.1016/j.ecresq.2009.09.001

Rous, B., Meyers, C., \& Stricklin, S. (2007). Strategies for supporting transitions of young children with special needs and their families. Journal of Early Intervention, 30(1), 1-18. https://doi.org/ 10.1177/2F105381510703000102
Shafritz, J. M., \& Ott, J. S. (2005). Classics of organization theory. Thomson/Wadsworth.

Starr, E. M., Martini, T. S., \& Kuo, B. C. H. (2016). Transition to kindergarten for children with autism spectrum disorder: A focus group study with ethnically diverse parents, teachers, and early intervention service providers. Focus on Autism and Other Developmental Disabilities, 31(2), 115-128. https://doi.org/10.1177/ 2F1088357614532497

United States Department of Education. (2009). Early School Transitions and the Social Behavior of Children with Disabilities: Selected Findings from the Pre-Elementary Education Longitudinal Study. https://ies.ed.gov/ncser/pdf/20093016.pdf

United States Department of Education. (2016). U.S. Department of Education Releases Guidance on Supporting Early Learning through the Every Student Succeeds Act. https://www.ed.gov/ news/press-releases/us-department-education-releases-guidancesupporting-early-learning-through-every-student-succeeds-act

Walker, S., Dunbar, S., Meldrum, K., Whiteford, C., Carrington, S., Hand, K., Berthelsen, D., \& Nicholson, J. (2012). The transition to school of children with developmental disabilities: Views of parents and teachers. Australasian Journal of Early Childhood, 37(3), 22-29. https://doi.org/10.1177/2F183693911203700304

Welchons, L. W., \& McIntyre, L. L. (2015). The transition to kindergarten for children with and without disabilities: An investigation of parent and teacher concerns and involvement. Topics in Early Childhood Special Education, 35(1), 52-62. https://doi.org/10. 1177/2F0271121414523141

Publisher's Note Springer Nature remains neutral with regard to jurisdictional claims in published maps and institutional affiliations. 